\title{
FOETUS STATUS AFTER R. v. SULLIVAN AND LEMAY
}

\section{K. MARK McCOURT*}

In the recent case of Sullivan and Lemay, the Supreme Court of Canada had to deal with the issue of foetal rights in a context not directly related to the abortion controversy. Mr. McCourt explores the implications of the Supreme Court's decision and the possibilities for future legislative action.
Dans la cause récente de Sullivan et Lemay, la Cour suprême a dâ traiter des droits du foetus dans un contexte qui n'est cependant pas directement lie au sujet controversé de l'avortement. Mark McCourt examine les implications de la décision et les actes législatifs qu' elle pourrait entraíner.

TABLE OF CONTENTS

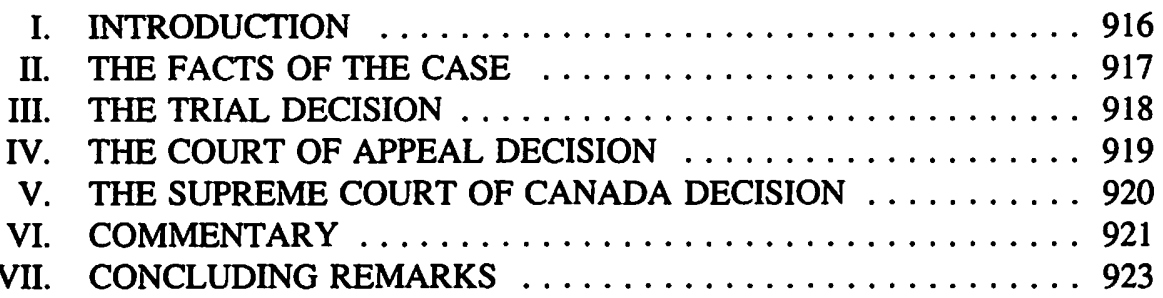

\section{INTRODUCTION}

Over the last few years, the Supreme Court of Canada has had a number of opportunities to consider foetal rights, and the case of $R$. v. Sullivan and Lemay is the court's latest word on the subject. In January of 1988, the court sidestepped the foetus status question while striking down the criminal abortion law in $R$. v. Morgentaler. Chief Justice Dickson remarked in that case:'

...the Court is not called upon in this appeal to evaluate any claim to "foetal rights" or to assess the meaning of "the right to life." I expressly refrain from so doing.

In March of 1989, again the court was able to avoid ruling on the existence and extent of foetal rights in Borowski v. Attorney General of Canada. ${ }^{2}$ "Pro-life" advocate Joseph Borowski argued that the exceptions outlined in the Criminal Code's abortion prohibition violated the Charter rights of unborn children. In a unanimous decision penned by Mr. Justice Sopinka, the court dismissed the appeal as moot, because the law to which the complaint related was no longer of force or effect as a result of the court's ruling in the Morgentaler case.

The court's third opportunity to examine the status of the foetus in Canadian law came a few months after its Borowski decision in the form of an emergency appeal by Chantal

Barrister and solicitor, Ackroyd, Piasta, Roth \& Day, Edmonton. The author wishes to thank Liana Beck for her assistance in the preparation of this article.

1. (1988), 1 S.C.R. 30 at 74.

2. (1989), 1 S.C.R. 342. 
Daigle. In that case, Jean-Guy Tremblay had successfully applied to the Quebec courts for an injunction prohibiting Ms. Daigle from aborting their child. The Quebec Court of Appeal upheld the injunction in July of 1989 on the basis of an interpretation that the Quebec Civil Code's human rights protection implicitly includes the unborn. Speaking for a three to two majority, Mr. Justice Bernier stated: ${ }^{3}$

\begin{abstract}
The child conceived but not yet bom, regardless of the term that is given to his civil status, constitutes a reality which must be taken into consideration. It is not an inanimate object, nor anyone's property, but a living human entity, distinct from that of the mother that carries it, which two human beings have given existence to, which they procreated, and which, at first blush, is entitled to life and to the protection of those who conceived it.
\end{abstract}

In flagrant violation of this ruling, Ms. Daigle obtained an abortion prior to the hearing of her appeal to the Supreme Court of Canada. Notwithstanding that her action arguably rendered the matter as moot as Borowski's case, the court unanimously allowed her appeal on the same day in which was heard, August $8,1989 .{ }^{4}$ The court probably made the immediate ruling to eliminate the likelihood that Ms. Daigle would be brought up on contempt of court charges for disobeying the injunction. In reasons released three months later, the court held per curiam that the injunction had to be set aside because the substantive rights which were alleged to support it - the rights of a foetus or of a potential father in respect of a foetus - do not exist at common law, in Quebec's Civil Code, or in Quebec's Charter of Human Rights and Freedoms.

Having held that no government action or legislation existed upon which to base injunctive relief, the court was able, as with its Borowski ruling, to avoid the issue of foetal rights under the Canadian Charter of Rights and Freedoms. Since the Dolphin Delivery case, ${ }^{5}$ the court has consistently held that the Charter applies to check the legislation and actions of government, and not the actions of private individuals like Ms. Daigle.

Partly as a result of the Daigle case, the federal government introduced abortion bill C-43 which passed the House of Commons in May of 1990 before dying in a stunning tie vote - ironically, 43 to 43 - in the Senate on January $31,1991$.

All of the foregoing set the stage for the Supreme Court's decision in $R$. v. Sullivan and Lemay rendered on March 21, 1991.

\title{
II. THE FACTS OF THE CASE
}

In September of 1984, Mr. and Mrs. Voth discovered that Mrs. Voth was pregnant with their first child, due in May of 1985. Initially, they planned to have the baby in a hospital with their family doctor in attendance, but as the due date drew nearer, the Voths changed

3. Tremblay v. Daigle (1989), 59 D.L.R. (4th) 609 at 613 (Que. C.A.).

4. Tremblay v. Daigle (1989), 2 S.C.R. 530.

s. $\quad$ R.W.D.S.U. v. Dolphin Delivery (1987), 1 W.W.R. 577 (S.C.C.). 
their minds and decided to have a home birth. Mrs. Voth learned of two midwives named Mary Sullivan and Gloria Lemay, and hired them to undertake the delivery of the baby. Neither Ms. Sullivan nor Ms. Lemay had any medical training, but both had experience as midwives.

Mrs. Voth went into labour on the evening of May 7, 1985. Shortly after the arrival of Ms. Sullivan and Ms. Lemay the next morning, Mrs. Voth was 100 percent dilated. After five hours of second stage labour, the baby boy's head emerged, but the mother's contractions had stopped. The midwives unsuccessfully attempted to deliver the child for some twenty minutes before finally telephoning emergency health services, who transported mother and child to the hospital. Within two minutes of arrival, the baby was delivered by an intern using a basic delivery technique. Unfortunately, it was too late. The baby had died from lack of oxygen.

Ms. Sullivan and Ms. Lemay were charged with criminal negligence causing the child's death contrary to Section 203 of the Criminal Code, ${ }^{6}$ and with criminal negligence causing bodily harm contrary to Section 204 of the Criminal Code. ${ }^{7}$ Those sections read as follows:

Section 203: Every one who by criminal negligence causes death to another person is guilty of an indictable offense and is liable to imprisonment for life.

Section 204: Every one who by criminal negligence causes bodily harm to another person is guilty of an indictable offense and liable to imprisonment for a term not exceeding ten years.

\section{THE TRIAL DECISION}

The case was tried by Madame Justice Godfrey of the British Columbia Supreme Court, without a jury. She ruled that the standard by which the accused were to be judged was "that of a competent child birth attendant whether the title is midwife, general practitioner or obstetrician." ${ }^{8}$ She branded as criminally negligent that the midwives:

a) failed to call for medical aid when it became apparent that Mrs. Voth's second stage labour was unusually difficult;

b) allowed Mrs. Voth to become so exhausted that her uterus ceased to contract; and

c) wasted precious time with ineffectual and potentially harmful attempts to deliver a baby when a "basic delivery technique" was all that was required. ${ }^{9}$

6. R.S.C. 1970 , c. C-34 (R.S.C. 1985 , c. C-46, s. 220).

7. Ibid. (R.S.C. 1985 , c. C-46, s. 221).

8. R. v. Sullivan and Lemay (1986), 31 C.C.C. (3d) 62 at 68 (B.C.S.C.).

9. Ibid. at 73 . 
The trial judge found that the actions of the midwives caused Mrs. Voth no bodily harm, unless the baby was part of the mother. However, she found that the criminal negligence of Ms. Sullivan and Ms. Lemay directly caused the death of the baby. This led to the vital question: by killing Mr. and Mrs. Voth's baby during delivery in a criminally negligent manner, had the midwives committed an act contrary to the Criminal Code? If the baby was a "person" within the meaning of the Code, then the accused were guilty of criminal negligence causing death. If the baby was part of the mother, then the accused were guilty of criminal negligence causing bodily harm.

Madame Justice Godfrey looked for guidance to the case of $R$. v. Marsh, a B.C. County Court decision rendered in 1979. In that case, the court ruled that ${ }^{10}$

the living foetus within the body of its mother and apparently a normal, vital and vigorous foetus, developed as a full-term child and in the very process of being born, was a person, within the meaning of Section 203 of the Criminal Code...

\section{Madame Justice Godfrey concluded,"}

I find the reasoning in $R$. v. Marsh appealing, especially as applied to the facts of this case, where the child was alive when the head was born and died because the accused were unable to complete the birth.

Ms. Sullivan and Ms. Lemay were convicted of criminal negligence causing death, and were acquitted of criminal negligence causing bodily harm.

\section{THE COURT OF APPEAL DECISION}

The midwives appealed their conviction to the British Columbia Court of Appeal, and the court rendered its per curiam decision on July $28,1988 .{ }^{12}$ Of course, the primary issue before the court in determining the validity of the conviction was whether or not Baby Voth was a "person" within the meaning of Section 203 of the Criminal Code. Former judge Thomas Berger, the lawyer for the midwives, argued that the baby was not a person because a live birth is a necessary precondition of personhood, and Baby Voth was stillborn. In support of this contention, Mr. Berger pointed to Section 206 of the Criminal Code which reads: ${ }^{13}$

(1) A child becomes a human being within the meaning of this Act when it has completely proceeded, in a living state, from the body of its mother whether or not (a) it has breathed, (b) it has an independent circulation, or (c) the navel string is severed.

(2) A person commits homicide when he causes injury to a child before or during its birth as a result of which the child dies after becoming a human being.

10. R. v. Marsh (1983) 2 C.C.C. (3d) 1 at 9.

11. Supra, note 7 at 74.

12. R. v. Sullivan (1988), 31 B.C.L.R. (2d) 145 (C.A.).

13. R.S.C. 1970 , c. C-34, s. 206 (R.S.C. 1985 , c. C-46, s. 223). 
Since Baby Voth clearly was not a "human being" within the meaning of Section 206, Mr. Berger argued persuasively that nor was Baby Voth a "person" under Section 203.

The court reviewed the status of the foetus at English, American and Canadian common law, noting that human rights have always been contingent upon a live birth. For example, in Montreal Tramways Company v. Leveille ${ }^{14}$ the Supreme Court held that a child injured while in the womb as a result of the mother's negligence had a cause of action only if it was subsequently born alive. In another example, $R$. v. Prince, ${ }^{15}$ the Supreme Court held that a person who had stabbed a pregnant woman, thereby causing premature labour and the death of her child moments after birth, could be tried for manslaughter of the child.

The court concluded that Baby Voth, who died while in the birth canal, had never achieved personhood for the purposes of Section 203 of the Code. The court held that at the time of the child's death, this baby boy was a part of his mother. Accordingly, the Court of Appeal overturned the conviction for criminal negligence causing death and substituted a conviction for criminal negligence causing bodily harm.

\section{THE SUPREME COURT OF CANADA DECISION}

The Crown appealed the Court of Appeal's decision to overturn the criminal negligence causing death conviction, and the midwives appealed their conviction for criminal negligence causing bodily harm. The Supreme Court of Canada heard these appeals together on October 30,1990, and rendered their decision five months later. In a brief and decisive $9-0$ ruling, the court dismissed the Crown's appeal. ${ }^{16}$ For the court, Chief Justice Lamer wrote:

I agree with the Court of Appeal that the introduction of the criminal negligence provisions by Parliament in 1954 was not intended to change the meaning of "person" and that the term, as used in Section 203 of the Code, is synonymous with the term "human being". Therefore, according to Section 206, the child of Jewel Voth was not a "person" within the meaning of Section 203 and Sullivan and Lemay cannot be convicted of criminal negligence causing death to another person.

With respect to the appeal of the midwives from their criminal negligence causing bodily harm conviction, the court ruled $8-1$ to allow the appeal on a technicality. Since the Crown had not appealed the trial judge's acquittal on the Section 204 charge, the Supreme Court held that it was beyond the Court of Appeal's jurisdiction to overturn that acquittal as they did.

In dissent, Madame Justice L'Heureux-Dubé found the Court of Appeal's substituted conviction entirely reasonable in the peculiar circumstances of the case. Both the trial judge and the Court of Appeal agreed that if Baby Voth was not a person, then it was part of the mother; and thus if the midwives through their criminal negligence had not caused

14. Montreal Tramways Company v. Leveille, [1933] S.C.R. 456.

15. R. v. Prince, [1986] 2 S.C.R. 480.

16. Sullivan and Lemay v. R. (21 March, 1991), S.C.J. No. 20 [unreported]. 
the death of a person, then necessarily the conclusion would be that they had done bodily harm to Mrs. Voth through the death of the foetus. Thus, according to Madame Justice L'Heureux-Dubé, justice required that a conviction for criminal negligence causing bodily harm be entered where the accused were acquitted on criminal negligence causing death.

\section{COMMENTARY}

After the Supreme Court's decision in $R$. v. Sullivan and Lemay, coupled with its ruling in Daigle, there can be little doubt that at least in civil and criminal law, a foetus is not considered a legal entity with a right to life unless legislative protection is expressly conferred. An example of legislation that clearly exists for the purpose of foetus protection is the section in the Criminal Code that prohibits intentionally killing an unborn child in the act of birth. Section 238(1) of the Code reads: ${ }^{17}$

Every one who causes the death, in the act of birth, of any child that has not become a human being, in such a manner that, if the child were a human being, he would be guilty of murder, is guilty of an indictable offense and liable to imprisonment for life.

After $R$. v. Sullivan and Lemay, it is clear that a child during birth is protected from those who intend to kill it but not from those who kill it prior to birth through wanton and reckless medical incompetence. This in no way precludes Parliament from passing legislation to protect children during birth from criminal negligence, as the B.C. Court of Appeal noted: ${ }^{18}$

If Parliament considers it appropriate to protect a child during the birth process from criminally negligent acts by those attending and assisting at the birth, that is a matter upon which Parliament can legislate.

Had the federal government's abortion bill survived the Senate, it too would have been an example of legislation with an expressed foetal protection purpose. Bill C- 43 proposed to permit abortions only where the pregnancy posed a threat to the mother's physical, mental or psychological health. While the wide definition of "psychological health" would likely have resulted in abortions on request, ${ }^{19}$ the stated purpose of the bill - to protect the unborn - was recognized in $R$. v. Morgentaler to be a reasonable legislative objective. $^{20}$

In provincial law, certain child welfare legislation has been interpreted by some lower level courts to include foetal protection. In Re Children's Aid Society for the District of

17. R.S.C. 1985 , c. C- 46 , s. $238(1)$.

18. Supra, note 11 at 160 .

19. Although the wide definition of "health" in Bill C-43 would likely have resulted in a rubber-stamping of abortion requests eventually, many pro-life Members of Parliament voted for the bill at the third reading nonetheless, hoping that the return of any abortion legislation to the Criminal Code would cause a "chilling effect", frightening abortionists into curbing their practice.

20. In Morgentaler, only one judge (Wilson J.) suggested that it would be contrary to the Charter to protect the unborm from abortion in the early stage of pregnancy. No other judge endorsed this suggestion. 
Kenora and J.L. ${ }^{21}$ the Ontario Family Court held that "child" in the Child Welfare Act included a foetus despite the lack of express wording to that effect. Similarly, in $R e$ Children's Aid Society of Belleville and T., ${ }^{22}$ the same court held that a certain unborn child was a "child in need of protection" under the Child and Family Services Act, 1984, again in the absence of express inclusion of foetuses in that Act. However, these two cases appear inconsistent with the Supreme Court's reasons both in $R$. v. Sullivan and Lemay and in the Daigle case, and therefore it is unlikely that they are of significant precedential value. This is not to say that provinces would be precluded from expressly protecting the foetus in child welfare statutes, although such legislation would be an encroachment, albeit perhaps a reasonable one, on the rights of pregnant women. For example, the Yukon's Children's Act, Section 133, reads: ${ }^{23}$

\footnotetext{
Where the director has reasonable and probable grounds to believe and does believe that a foetus us being subjected to a serious risk of suffering from foetal alcohol syndrome or other congenital injury attributable to the pregnant woman subjecting herself during pregnancy to addictive or intoxicating substances, the director may apply to a judge for an order requiring the woman to participate in such reasonable supervision or counselling as the order specifies in respect of her use of addictive or intoxicating substances.
}

It is important to note that in $R$. v. Sullivan and Lemay, as in Daigle, Borowski and Morgentaler before it, the Supreme Court managed to avoid the issue of the status of the foetus in constitutional law. Thus, the issue of whether a foetus has a right to life under section 7 of the Canadian Charter of Rights and Freedoms is as yet undetermined by the Supreme Court of Canada. Section 7 reads:

Everyone has the right to life, liberty and security of the person and the right not to be deprived thereof except in accordance with the principles of fundamental justice.

Is it likely that the Supreme Court will hold that "everyone" includes the unborn, in the absence of express wording to include the unborn in section 7? Past decisions, and particularly Daigle and Sullivan and Lemay, would seem to indicate a trend against such an interpretation. However, it is at least possible that a "large and liberal" interpretation of section 7 of the Charter would lead to the inclusion of the unborn within its protective ambit. Such a decision would be nearly unprecedented, and perhaps would be best compared with Lord Sankey's classic decision in the Persons Case. ${ }^{24}$ In that case, the Privy Council overturned a unanimous decision of the Supreme Court of Canada ${ }^{25}$ and held that the word "persons" in the Canadian constitution includes women. While it went against all precedent, the correctness of the decision surely cannot be denied.

21. (1981), 134 D.L.R. (3d) 249 (Ont. Prov. Ct. Fam. Div.).

(1987), 59 O.R. (2d) 204 (Prov. Ct. Fam. Div.).

R.S.Y. 1986, c. 22, s. 133.

Edwards v. A.G. Canada, [1930] A.C. 124.

Reference Re Meaning of the Word "Persons" in Section 24 of the B.N.A. Act, [1928] S.C.R. 276. 
Whether or not the courts recognize a foetal status in section 7 of the Charter, it appears that section 1 of the Charter will protect the state's compelling interest in foetal life. Section 1 reads:

The Canadian Charter of Rights and Freedoms guarantees the rights and freedoms set out in it subject only to such reasonable limits prescribed by law as can be demonstrably justified in a free and democratic society.

It is through this section that a woman's section 7 right to liberty and security of her person may be reasonably limited to protect the foetus through abortion legislation or laws aimed at protecting the foetus from maternal substance abuse or the medical incompetence of others.

For example, Parliament could enact a law that would permit abortions in cases of rape, incest, severe foetal abnormality or genuinely serious threat to the physical or psychiatric health of the mother, but would prohibit abortions sought for social or economic reasons or as a means of birth control. While such a law would certainly impede the priorities and aspirations of women wanting non-therapeutic abortions and therefore might be an infringement of section 7 of the Charter, arguably the law would be justified as a reasonable limit on liberty and security, pursuant to section 1 of the Charter. As Law Reform Commissioner Joseph Maingot stated in Crimes Against the Foetus: ${ }^{26}$

In the Morgentaler decision, a majority (Beetz, Estey, McIntyre and LaForest JJ.) make it abundantly clear that a life and health standard does not violate the right to security of the person under the Charter.

Mr. Justice Beetz suggested not only that a procedurally fair abortion law could limit abortions to reasons relating to life and health, but that such a law could reasonably require a second medical opinion, given the importance of the foetal life. He stated: ${ }^{27}$

I do not believe it to be unreasonable to seek independent medical confirmation of the threat to the woman's life or health when such an important and distinct interest hangs in the balance.

\section{CONCLUDING REMARKS}

The case of $R$. v. Sullivan and Lemay is a valuable addition to the body of jurisprudence concerning the status of the foetus in Canadian law. While foetal rights advocates cannot be pleased with this ruling, the reasoning of the Supreme Court at least with respect to the Crown's appeal appears sound. It was not for the court to determine whether or not children during birth should be protected from criminal negligence; the court's duty was strictly to interpret Section 203 in light of other sections of the Criminal Code to determine whether it does protect the unborn. 
It is more clear than ever that federal and provincial laws offer scant protection for the foetus. It is submitted that Parliament and legislatures would be well advised at least to consider proposed legislation aimed at enhancing the status of the foetus. ${ }^{28}$ While some

A proposal to that effect, drafted by the writer and Edmonton Liberal M.P. David W. Kilgour, is set forth:

\section{THE HOUSE OF COMMONS OF CANADA}

\section{BILL C-287}

An Act to amend the Criminal Code

(abortion)

Her Majesty, by and with the advice and consent of the Senate and House of Commons of Canada, enacts as follows:

R.S., c. C-46 1. (1) Subsection 287(1) of the Criminal Code is repealed and the following substituted therefor:

Procuring miscarriage

\section{Exceptions}

Preserving the life of the female person

\section{Definitions}

"approved institution"

"qualified medical practitioner"
"287. (1) Every one who, with intent to procure the miscarriage of a female person, uses any means for the purpose of carrying out his intention is guilty of an indictable offence and liable to imprisonment for a term not exceeding five years."

(2) Subsections 287(4) to (7) of the said Act are repealed and the following substituted therefor:

"(4) Subsections (1) and (2) do not apply where the miscarriage is procured by a qualified medical practitioner in an approved institution before the sixteenth week of gestation, and

(a) continuation to viability of the pregnancy is determined by two qualified medical practitioners in the province to pose a serious threat to the physical or mental health of the female person;

(b) the pregnancy is the result of an act of incest or sexual assault; or

(c) the female person is carrying a foetus which is determined by two qualified medical practitioners in the province to be seriously and incurably deformed or seriously and incurably diseased.

(5) Subsections (1) and (2) do not apply where procuring the miscarriage of the female person is necessary to preserve her life.

(6) For the purposes of this section,

"approved institution" means a hospital or clinic in a province approved for the purposes of this section by the Minister of Health of that province as having the requisite medical staff and facilities to perform abortion procedures safely;

"qualified medical practitioner" means a person entitled to practice medicine under the laws of the province in which the abortion procedure is performed; 
form of abortion legislation and laws protecting the unborn from wanton or reckless abuse would generally infringe on the liberty and security of pregnant women, it is likely that the state interest in foetal protection and possibly even the foetal right to life would justify at least some infringements in this regard. After $R$. v. Sullivan and Lemay, the controversial issue of foetus status is back with government.

\footnotetext{
"serious threat" "serious threat" includes for greater certainty, a genuine and substantial medical or psychiatric health threat but does not include considerations of a social or economic nature;

"viability" "viability" means the stage of development at which a foetus is capable of surviving outside of a pregnant female person."
} 